\title{
Penguatan Keterampilan Berbahasa Inggris Siswa SMP melalui Apresiasi Puisi di Jampang English Village Bogor
}

\author{
Ni Komang Ariani ${ }^{1}$, May Triranto Maharini ${ }^{2}$, Ruisah $^{3}$ \\ Universitas Pamulang \\ Korespondensi: dosen01154@unpam.ac.id ${ }^{1}$,dosen01169@unpam.ac.id ${ }^{2}$, \\ dosen00300@unpam.ac.id ${ }^{3}$
}

\begin{abstract}
Most surveys indicate that the rate of Indonesian people's reading habit is still low. Based on survey in 2015, Indonesia was ranked 69th from 78 countries. That means that Indonesia was one of the countries that have low interest in reading. In south east asia, Indonesia is placed as the second lowest country with reading interest which is only one level better than Timor Leste. As in fact, people's reading interest or reading habit can be boosted through some strategies. One of them is by introducing teenagers with literature like poetry. Poetry might be the most appropriate work to be introduced to teenagers. While the target of this social service program are the students of elmentary school level, the poetry works that are used are short English poems. These poems are believed can boost the students' interest in reading especially literature. Music, which is the sound of guitar, accompanies the students while the poetry is read. This is aimed to make the students more easily understand the lyrics of the poetry. The expectation of using this strategy is to make students get more interested in reading and knowing deeper about literature.
\end{abstract}

Keywords: literacy, literature, poetry

\begin{abstract}
Abstrak
Tingkat membaca masyarakat Indonesia masih sangat rendah. Berdasarkan data survei 2015, Indonesia menduduki peringkan ke-69 dari 78 negara di Asia berdasarkan tingkat membacanya. Sedangkan di Tingkat Asia tenggara, Indonesia menduduki peringkat ke-2 terendah setelah Timor Leste. Minat baca dapat ditumbuhkan melalui berbagai macam strategi. Salah satu strategi yang dapat diambil adalah dengan mengenalkan remaja dengan karya sastra, termasuk di dalamnya puisi. Mengingat target program PKM ini adalah siswa pada tingkat SD, maka puisi yang digunakan juga adalah puisi-puisi pendek berbahasa Inggris yang dapat merangsang minat kepada karya sastra. Selain itu, pengenalan puisi ini juga disertai dengan musik pengiring yaitu gitar, agar lebih mudah diterima oleh para peserta didik. Melalui pengenalan puisi dan musik inilah, kami berharap remaja semakin berminat untuk membaca dan mendalami karya sastra. Pemilihan medium ini puisi, ke depan diharapkan dapat merangsang minat baca anak didik, untuk membawa puisi-puisi lainnya, kemudian dilanjutkan dengan membaca cerpen dan novel, yang kaya dengan nilai-nilai literasi. Selain itu, kegiatan ini merupakan bagian dari menjalankan kewajiban untuk melaksanakan Tri Dharma Perguruan Tinggi berdasarkan pada pasal 20 UU No. 20 Tahun 2003 tentang Sistem Pendidikan Nasional (UU Diknas).
\end{abstract}

Kata kunci: literasi, sastra, puisi 


\section{A. Pendahuluan}

Menurut kamus online Merriam Webster, kata "literacy" berarti "the quality or state of being literate atau "educated, cultured". Maksud arti yang tertera pada kamu tersebut adalah bahwa literasi menunjukkan kualitas sebuah bangsa. Sebuah bangsa dianggap berbudaya dan terdidik jika melek dan kritis untuk melihat berbahagai persoalan bangsa.

Menurut Most Literate Nation in the World, tahun lalu, Indonesia berada di peringkat 60 dari 61 negara. (Kompas.com, 3 April 2017). Hal ini menunjukkan bahwa literasi di Indonesia masih sangat rendah. Apalagi jika dikaitkan dengan minat baca masyarakat Indonesia yang masih jauh dibandingkan dengan negaranegara lain. Data UNESCO yang pernah dilansir pada 2012 menyebutkan indeks minat baca di Indonesia baru mencapai 0,001 atau satu orang yang memiliki minat baca dari setiap seribu penduduk. (Tirto.id, 1 Mei 2017). Jadi hanya satu orang yang memiliki minat baca dari seribu penduduk. Selain itu, indeks pembangunan manusia di Indonesia juga masih kalah dibandingkan negara-negara tetangga. Menurut data penelitian yang dilakukan oleh UNDP, Indeks Pembangunan Manusia di Indonesia masih tergolong rendah, yaitu hanya 14, 6\%, sementara Malaysia $28 \%$ dan Singapura $33 \%$ (Kumparan, 10 September 2017).

Melalui kegiatan ini kami berharap dapat memantik minat baca remaja terhadap karya sastra. Untuk itu, kami memulai dengan mengenalkan puisi-puisi berbahasa Inggris sesuai dengan usia peserta didik. Dalam hal ini peserta didik berusia sekolah dasar atau pada level elementary. Untuk makin mudah diterima oleh peserta didik, kami memadukannya dengan musik, yang akrab dan dekat dengan anak-anak remaja. Pengenalan musik dan puisi juga dilakukan melalui pemutaran video-video sejenis dari media youtube. Melalui media-media populer ini, diharapkan lebih mudah untuk dapat diterima oleh anak-anak remaja masa kini.

Selain itu sebagai bagian dari program studi Sastra Inggris, maka peningkatan kosa kata Bahasa Inggris juga menjadi bahan pertimbangan kami. Maka puisi yang dipilih dalam kegiatan ini adalah puisi berbahasa Inggris sesuai dengan usia peserta didik. Pemilihan puisi ini kami anggap selaras dengan program pengajaran Bahasa Inggris yang sudah berlangsung sejak lama di Jampang English Village (JEV) sebagai sebuah lembaga yang memberikan pengajaran Bahasa Inggris kepada masyarakat setempat yang membutuhkan. Buku puisi berbahasa Inggris ini dimaksudkan untuk semakin memperkaya khasanah kosakata Bahasa Inggris remaja di Jampang English Village.

Selain itu, kami juga mengharapkan agar para peserta dapat mengapresiasi keindahan kata-kata dalam puisi tersebut, apalagi jika disertai dengan alunan musik. Selain itu, pada program PKM ini mahasiswa Unpam dapat pula melatih kemampuannya untuk mengorganisasi kegiatan dan menghasilkan sebuah produk bersama berupa musikalisasi berbahasa Inggris. Pada saat yang sama para dosen sastra Inggris Unpam juga dapat memberikan bimbingan dan konsultasi selama proses ini berlangsung. Melalui program ini diharapkan dapat tercapai dua tujuan seperti kata pepatah: Sekali Merengkuh Dayung Dua Tiga Pulau Terlampaui. Manfaat pertama yang diharapkan dalam program ini adalah peningkatan minat baca dan karya sastra. Sementara manfaat kedua yang ingin dicapai adalah 
khasanah kosakata siswa dalam Bahasa Inggris sebagaimana tujuan dari kegiatan di Jampang English Village.

Sastra menjadi penting karena menurut krititus sastra, A Teeuw, "Membaca sajak adalah sebuah proses kreatif_bahwa pembacalah yang memberi makna." (Junaedhie, 2017, p. 3). Pentingnya membaca puisi ini, juga disampaikan oleh penyair Acep Zamzam Noor sebagai berikut:

Membaca puisi adalah menangkap kilatan-kilatan pikiran dan perasaan yang diungkapkan oleh penyair.

Seorang pembaca akan tergetar perasaannya dan merinding bulu kuduknya jika kilatan-kilatan pikiran dan perasaan yang ditembakkan sang penyair mengenai sasarannya, yakni pikiran dan perasaan pembaca yang terdalam. (Junaedhi, 2017, p. 9)

Pendapat ini juga mendapat dukungan dari almarhum sastrawan, Arie M. P. Tamba. Ia mengungkapkan bahwa "Sastra memelihara imajinasi dan peluang daya guna bahasa lewat prosa dan puisi. Sastra membuat masa lalu, masa kini dan masa datang jadi menjanjikan untuk dijenguk, dipersoalkan dan bahkan diciptkan. Bukankah peran sastra itu dahsyat?" (Junaedhi, 2017, p. 22).

Penyair Joko Pinurbo (2017) yang telah meraih berbagai penghargaan sastra menyampaikan bahwa dengan berpuisi seseorang dapat memperoleh kebebasan dan melepaskan diri dari ikatan. Melalui puisi pula, seorang pembaca dapat melatih empatinya. Dalam menulis puisi, Pinurbo mengatakan ia akan menempatkan dirinya dalam posisi orang lain dan membuat seseorang menjadi lebih bijak. (Junaedhi, 2017, p. 117). Melalui pendapat para sastrawan tersebut maka dapat disimpulkan bahwa sastra mempunyai peran yang sangat penting. Maka mengapreasi karya sastra menjadi sangat penting.

Sedangkan mengenai setting tempat untuk pengenalan sastra berupa puisi untuk meningkatkan motivasi siswa dalam membaca, seperti setelah disebutkan sebelumnya, adalah Jampang English Village. Jampang English Village merupakan program kursus berbahasa Inggris gratis yang diiniasi oleh Dompet Dhuafa. Dompet Dhuafa sendiri adalah yayasan yang bergerak dalam bidang filantropi yang memiliki lima pilar program utama yang memiliki tujuan besar dalam mengentaskan kemiskinan. Lima pilar tersebut adalah dalam bidang pendidikan, kesehatan, ekonomi, sosial dan dakwah, serta budaya. Jampang English Village adalah sebuah program yang disediakan untuk pilar pendidikan milik Dompet Dhuafa. Tujuan dari program ini adalah untuk memberikan pendidikan Bahasa Inggris bagi pedagang di kawasan wisata Jampang. Melalui hadirnya Jampang English Village, maka anak-anak dan dewasa akan makin tertarik untuk belajar Bahasa Inggris. Dengan demikian kawasan wisata Jampang tidak hanya dikenal oleh wisatawan lokal saja, namun juga wisatawan mancanegara. Kawasan ini memiliki luas sekitar tiga hektar. Selanjutnya kawasan Jampang juga diharapkan dapat menjadi kawasan wisata belajar Bahasa Inggris bagi pengunjung.

Menurut laporan harian Republika (30 Maret 2015), pada tahap awal, JEV dimulai dengan mendidik komunitas pandu desa yang ada dengan anggota sebanyak 30 orang. Selanjutnya, masyarakat luas baik itu pelajar, pemuda desa, karang taruna, remaja masjid, ibu-ibu PKK, ibu-ibu majelis taklim, guru, dan 
komunitas lainnya dengan target 1000 orang bergabung untuk belajar Bahasa Inggris di tahun 2015. JEV menggunakan balai pertemuan desa, mushola, saungsaung dan lapangan sebagai lokasi untuk belajar berbahasa Inggris sekaligus mencari nafkah bagi masyarakat. Untuk mempermudah proses belajar, menu makanan di warung-warung dan toko di kawasan JEV akan ditulis dalam Bahasa Inggris. Di tempat-tempat umum seperti pos ronda, masjid dan mushola, dindingdinding tempat belajar juga akan ditempel informasi atau ungkapan-ungkapan dalam Bahasa Inggris sehingga membantu dalam belajar. Papan penunjuk jalan juga akan dibuat dalam Bahasa Inggris.

Sebagaimana yang dilaporkan oleh laman Okezone pada tanggal 3 Mei 2016, Jampang English Village merupakan upaya untuk memberikan kursus Bahasa Inggris gratis kepada siapa saja yang ingin belajar Bahasa Inggris, terutama mereka yang tinggal di Jampang. Jampang merupakan sebuah perkampungan Betawi yang terletak di perbatasan Bojongsari, Depok dengan Parung, Kabupaten Bogor. Sejauh ini, sudah cukup banyak pihak yang terlibat menjadi pengajar di JEV, mulai dari alumni, mahasiswa atau para dosen yang sedang melaksanakan kegiatan PKM. Dalam laman itu dipaparkan bahwa menurut pembina JEV, Ann Eastlake pada tahun 2016 ada 754 anak yang menjadi penerima manfaat program ini.

Melalui analisis terhadap situasi tersebut, maka dapat diidentifikasikan masalah-masalah yang dihadapi mitra dalam program pengabdiaan masyarakat kali ini adalah kebutuhan untuk meningkatkan kemampuan berbahasa Inggris melalui berbagai kegiatan yang bersifat praktis, kebutuhan untuk meningkatkan tingkat literasi dan minat baca, kebutuhan untuk menghasilkan sebuah produk yang berkaitan dengan karya sastra yang bermakna.

Pada kesempatan pengabdian kepada masyarakat kali ini para mahasiswa sastra Inggris Universitas Pamulang dengan bimbingan dosen Sastra Inggris akan membacakan dan memainkan musik dengan puisi berbahasa Inggris yang dikhususkan untuk siswa sekolah dasar. Di dalam kegiatan tesebut pun para mahasiswa UNPAM yang terlibat dalam program ini turut belajar memberikan panduan dan bimbingan terhadap para siswa usia SD tersebut untuk belajar membacakan puisi. Dengan demikian apresiasi terhadap karya sastra juga bersamaan dengan peningkatan khasanah kosakata siswa dalam Bahasa Inggris. Judul pengabdian kepada masyarakat yang akan dilaksanakan selama tiga hari ini adalah "Penguatan Keterampilan Berbahasa Inggris Siswa SMP melalui Apresiasi Puisi di Jampang English Village Bogor".

Melalui kegiatan ini, diharapkan akan dapat dicapai sejumlah manfaat diantaranya:

1. Bagi para siswa Jampang, pelatihan ini diharapkan dapat memberikan wadah untuk kreatifitas melalui apresiasi karya sastra dan memadukannya dengan musik. Pengenalan musik dan sastra untuk memberikan angin segar dan semangat baru bagi remaja di dalam mengenal sastra.

2. Bagi para civitas akademika dan dosen Prodi Sastra Inggris, pengabdian masyarakat ini dapat dijadikan sebagai wahana yang tepat untuk mengamalkan ilmu serta sebagai wujud dari pengabdian masyarakat yang merupakan bagian dari Tri Dharma Perguruan Tinggi. 
3. Kegiatan ini diharapkan dapat memperkaya khasanah kosakata siswa dalam Bahasa Indonesia dan Bahasa Inggris

Permasalahan yang dihadapi dalam PKM ini adalah rendahnya minat baca masyarakat pada umumnya termasuk rendahnya minat baca di kalangan remaja. Khususnya remaja yang menjadi lokasi pengabdian terhadap masyarakat yaitu Jampang English Village. Pada saat yang sama, kawasan ini merupakan komunitas untuk belajar Bahasa Inggris. Sastra bagi kami memiliki peran yang sangat penting dalam meningkatkan literasi di masyarakat, agar Indonesia tak lagi berada di peringkat 60 dari 61 negara di Most Literation in the World atau hanya 1 dari 1000 penduduk yang memiliki minat baca sebagaimana dilaporkan oleh Tirto.id. Rendahnya literasi ini sangat berbahaya apalagi di masa digital ini.

Menurut Asosiasi Penyelenggara Jasa Internet Indonesia (APJII), 55 persen penduduk Indonesia (sekitar 132 juta jiwa) adalah pengakses internet. 54 persen pengguna Facebook dan 5, 54 persen pengguna Twitter. Data lembaga penelitian Nielsen yang menyebutkan penduduk Indonesia yang setiap hari menghabiskan waktu berselancar di dunia maya menggunakan komputer selama empat jam 42 menit, browsing di telepon genggam selama tiga jam 33 menit dan menghabiskan waktu di sosial media selama dua jam 51 menit (Tirto.id, 1 Mei 2017). Sementara itu, di Indonesia berita bohong mudah menyebar karena masyarakat sangat aktif menggunakan media sosial (Kompas, 18 April 2017).

Sangatlah tepat bila pengenalan pada puisi karya anak bangsa merupakan salah satu upaya untuk meningkatkan tingkat melek sastra di kalangan remaja. Kegiatan ini dimaksudkan untuk memperkenalkan dan menyebarluaskan karya sastra berupa puisi di kalangan siswa SD dan SMP dan memadukannya dengan musik yang dekat dengan kehidupan mereka sebagai remaja.

Terekspos dengan kata-kata indah dalam karya sastra, sekaligus dapat menambah khasanah kosa kata mereka dalam Bahasa Inggris. Dengan demikian, kegiatan ini dapat memberikan manfaat bagi siswa SD di Jampang English Village berupa wadah untuk kreatifitas melalui apresiasi karya sastra dan memadukannya dengan musik. Sementara bagi para civitas akademika dan dosen Prodi Sastra Inggris, pengabdian masyarakat ini dapat dijadikan sebagai tepat untuk mengamalkan ilmu serta sebagai wujud dari pengabdian masyarakat yang merupakan bagian dari Tri Dharma Perguruan Tinggi.

\section{B. Pelaksanaan dan Metode}

Program kegiatan terhadap Masyarakat (PKM) dilaksanakan ini melalui perencanaan selama 6 bulan, melalui berbagai proses survey, perencanaan, pengajuan proposal, pelaksanaan dan penyampaian laporan yang akan dilakukan pada awal bulan Januari 2020. Kegiatan ini merupakan kegiatan yang melibatkan proses menghasilkan karya seni, oleh karena itu, proses memerlukan beberapa tahapan yang menentukan. Metode pelaksaan meliputi kegiatan:

\section{Pelatihan}

Kegiatan awal yang dapat diberikan adalah memberikan latihan cara-cara membuat musikalisasi puisi. Tahap pertama dilakukan dengan menunjukkan 
contoh-contoh musikalisasi puisi yang dilakukan oleh pihak yang berkompeten. Tahap kedua dilakukan melalui menghadirkan narasumber yang memiliki keahlian di bidang ini. Narasumber pertama berkaitan erat dengan keahlian menghasilan irama musik dari gitar. Narasumber ini akan dihadirkan melalui mahasiswa Unpam yang ahli di bidangnya. Narasumber kedua berkaitan dengan kemampuan untuk memahami perpaduan antara irama nada dan alat musik. Narasumber kedua ini dihadirkan melalui kerjasama mahasiswa Unpam dan dosen Unpam melalui mata kuliah Poetry.

\section{Pendampingan}

Pada kegiatan ini dosen dan mahasiswa Unpam melakukan pendampingan dan brainstorming mengenai musik dan puisi yang dimusikalisasi. Mahasiswa dan peserta PKM dapat memberikan pendapat dan usulan mengenai musik yang dapat digunakan. Membuat musikalisasi puisi bukanlah pekerjaan yang mudah. Dalam hal ini adalah upaya untuk menggabungkan dua karya seni. Seni musik dan seni puisi. Hal ini bukanlah hal yang sederhana untuk dipahami oleh siswa sekolah SD dan siswa SMP. Namun bukan berarti ini merupakan pekerjaan yang tidak mungkin. Apalagi niat dari kegiatan ini adalah mengenalkan sastra sedini mungkin kepada siswa, yang di kemudian hari diharapkan dapat meningkatkan minat siswa terhadap karya sastra dan minat baca secara umum.

\section{Praktek}

Pada kegiatan ini para peserta PKM dan Mahasiswa langsung dapat mempraktekkan ide-idenya melalui iringan alat musik seperti gitar dan menyesuaikan dengan lirik puisi yang diberikan. Proses ini akan berlangsung selama tiga hari. Tidak hanya di tempat pelatihan, namun juga di rumah masingmasing peserta PKM. Peserta PKM disarankan untuk terus memperkaya dirinya dengan contoh-contoh musikalisasi puisi yang diperoleh di youtube. Contohcontoh yang disarankan adalah contoh-contoh yang dilakukan oleh Ari-Reda dalam melakukan musikalisasi puisi-puisi Sapardi Djoko Damono.

Proses pelaksanaan PKM sendiri meliputi sejumlah tahap mulai bulan September 2019 sampai dengan bulan Januari 2020. Diantaranya pada bulan September dilakukan diskusi dengan penanggung jawab dari Jampang English Village, di bulan Oktober dilakukan survey lokasi dan penyusunan proposal PKM. Pada bulan November PKM dilaksanakan selama tiga hari. Sementara itu penyusunan laporan PKM dan pelaporan PKM dilaksanakan pada bulan Desember dan Januari.

Berikut ini tempat, sasaran, dan waktu pelaksanaan kegiatan pengabdian masyarakat adalah sebagai berikut:

1. Tempat Kegiatan : Kampung Bahasa Inggris Jampang

2. Sasaran Kegiatan : Siswa SD dan SMP

3. Waktu Pelaksanaan Kegiatan
Hari/Tanggal
: 8, 9, 10 November 2019
Waktu
: 13.30- 17.00.

Adapun rangkaian kegiatan harian meliputi:

1. Ice breaking: games 
http://openjournal.unpam.ac.id/index.php/ACB/issue/view/605/showToc

2. Pembagian siswa ke dalam kelompok-kelompok kecil

3. Kelompok-kelompok kecil dibantu oleh mahasiswa Sastra Inggris dan dosen Sastra Inggris

4. Diskusi makna puisi dan kaitannya dengan kehidupan masing-masing

5. Pemutaran musikalisasi puisi dari Youtube

6. Proses kreatif menciptakan karya puisid an musik

7. Diskusi dan latihan dilanjutkan di rumah masing-masing

8. Persiapan pementasan musik dan puisi

9. Penutupan dan ramah-tamah

Adapun puisi yang digunakan dalam kegiatan ini adalah sebagai berikut:

\section{Roses are red}

Roses are red

Violets are blue

Sugar is sweet

And so are you

2. Daffodil

Yellow, yellow daffodil, dancing in the sun

Oh yellow, yellow daffodil, you tell me spring has come

I can hear a blue bird sing, and hear a robin call

But yellow, yellow daffodil I love you most of all

3. Daisy

I'm a little daisy, tall and slim

Here are my petals, here is my stem

When the sun comes up and the rain comes down

I grow, grow, grow-up from the ground

4. Sunflower

Sunflower, sunflower, standing straight and tall

Sunflower, sunflower, you're the tallest flower of them all

Sunflower, sunflower, when your seeds fall to the ground

Sunflower, sunflower, by the squirells they'll be found

5. Roses

Roses in the winter time

Roses in the fall

The roses in my garden

At the nicest of them all

Every fragrant, always sweet

Oh how I love the rose

I really think and feel it is

The nicest flower that grows

6. Snowy Day

Snow, snow, snow

Falls from the sky

Cold, cold, cold

I wonder why

Throw a snowball,

Build a snowman, 
http://openjournal.unpam.ac.id/index.php/ACB/issue/view/605/showToc

It is such a great fun

Bundle up in the winter clothes

Stay warm without the sun

\section{A Litte Elf}

A little elf

Sat in a tree

Painting leaves

To throw at me

Leaves of yellow

And leaves of red

Came trumbling down

About my head

8. Rainbow fish

Rainbow fish,

Rainbow fish

Swimming in the sea

Will you please share a scale with me?

9. Weather is a funny thing

It's often rainy in the Spring

Summer, hot and very sunny

Flowers bloom and bees make honey

In autumn the leaves are falling down

Kids jump in piles on the ground

Winter has a lot of snow

So, hop on a sleigh, come-on, let's go

\section{Hasil dan Pembahasan}

Kegiatan PKM yang berlangsung selama tiga hari melibatkan 12 mahasiswa yang dibagi ke dalam kelompok-kelompok kecil yang membahas puisi-puisi yang berbeda. Mahasiswa sastra Inggris Unpam membantu peserta didik memahami isi puisi dalam Bahasa Indonesia kemudian cara membacakannya dalam Bahasa Inggris. Kelompok-kelompok kecil ini lebih efektif oleh karena anak-anak didik dapat bertanya tanpa merasa malu. Mahasiswa Sastra Inggris Unpam juga memberikan games-games berkaitan penambahan kosakata Bahasa Inggris seputaran tema puisi yang sedang dibahas.

Pada tahapan selanjutnya, setelah masing-masing puisi dipahami dengan baik, dimulailah pengenalan alat musik yang akan digunakan untuk mengiringi puisi. Peserta didik berlatih membacakan puisi dengan suara yang lantang sekaligus mengandung unsur dramatis dan storytelling.

Kemudian, mahasiswa Unpam bekerjasama dengan peserta didik, membuat produk art dan craft sebagai penerjemahan puisi ke dalam bentuk yang berbeda. Produk art and craft ini juga berfungsi sebagai poster pada bagian pementasan bersama. 


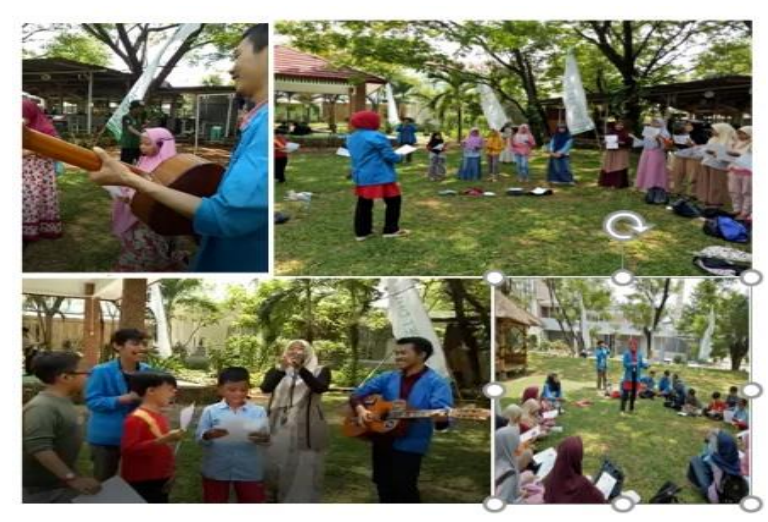

Gambar 1. Kegiatan Musikalisasi Puisi

Para peserta didik terlihat cukup antusias menikmati keindahan kata-kata dalam puisi sekaligus dapat memperkaya khasanah kosakata yang mereka miliki. Pembelajaran spelling dan vocabularies juga menjadi bagian dari kegiatan ini. Suasana sejuk dan kerindangan Jampang English Village cukup membantu pembacaan puisi yang bertema benda-benda yang cukup dekat dengan mereka, seperti bunga mawar, dedaunan, iklan, salju dan jenis-jenis bunga lainnya.

Maka tepatlah sebagaimana yang disampaikan oleh Acep Zamzam Noor bahwa "Membaca puisi adalah menangkap kilatan-kilatan pikiran dan perasaan yang diungkapkan oleh penyair." (Junaedhi, 2017, p. 9) atau Teuw, "Membaca sajak adalah sebuah proses kreatif_bahwa pembacalah yang memberi makna." (Junaedhie, 2017, p. 3). Melalui pengenalan puisi ini, maka diharapkan minat baca anak-anak terhadap karya sastra, seperti apa yang diperlihatkan siswa-siswi JEV, menjadi meningkat.

\section{Penutup}

\section{Simpulan}

Selama tiga hari pelaksanaan PKM yang dilanjutkan dengan latihanlatihan di rumah masing-masing oleh peserta, dapat disimpulkan bahwa anak-anak peserta PKM cukup tertarik dengan puisi dan sangat menikmati pengenalan puisi melalui musik dan musikalisasi puisi. Selain itu dapat disimpulkan bahwa menggabungkan dua karya seni antara musik dan puisi bukan merupakan pekerjaan yang mudah, dan dapat dilakukan dalam waktu singkat. Baik pelatih maupun peserta masih kesulitan untuk menciptakan musikalisasi puisi, namun baik peserta maupun pelatih cukup antusias dan menikmati kegiatan pembacaan dan apresiasi puisi dengan diiringi oleh alat musik.

\section{Saran}

Melalui kegiatan ini, kami berharap bahwa sastra tidak lagi menjadi sesuatu yang asing bagi anak-anak dan remaja. Sastra merupakan sesuatu yang dekat dan mengasyikkan. Lebih mengasyikkan lagi ketika diiringi oleh musik. Sastra demikian penting bagi kehidupan sesuatu bangsa.

Sementara itu, menurut Rene Wellek dan Austin Warren (1977), Sastra "menyajikan kehidupan" dan "kehidupan" sebagian besar terdiri dari kenyataan sosial." Sementara itu, menurut dosen Universitas Indonesia, Melani Budianta, 
"sebuah karya sastra lahir dari suatu masyarakat yang menciptakan ruang gerak tertentu bagi kesusastraan melalui kebijakan budaya, politik bahasa dan birokrasi kesenian."

Maka sastra menjadi demikian pentingnya untuk mewujudkan bangsa yang melek, atau bangsa yang memiliki tingkat literasi tinggi. Sebagaimana kamus merriem.webster mendefinisikan bahwa literasi berkaitan kualitas untuk melek, terdidik dan berbudaya. Artinya literasi menunjukkan kualitas sebuah bangsa. Sebuah bangsa dianggap berbudaya dan terdidik jika melek dan kritis untuk melihat berbagai persoalan bangsa.

\section{DAFTAR PUSTAKA}

Debora, Y. (2017). Literasi Rendah Sebabkan Masyarakat Mudah Percaya Hoax. Diakses dari https://tirto.id/literasi-rendah-sebabkan-masyarakat-mudahpercaya-hoax-cnQa.

Dompetdhuafa.com. (2014). Jampang English Village. Diakses dari http://www.dompetdhuafa.org/post/detail/2014/jampang-english-village-$\%$ E2\%80\%9Ckampung-inggris\%E2\%80\%9D-yang-memikat

Gewati, M. (2016). Minat Baca Indonesia Ada di Urutan ke-60 Dunia. Diakses pada tanggal $15 \quad$ September 2019 dari https://edukasi.kompas.com/read/2016/08/29/07175131/minat.baca.indonesi a.ada.di.urutan.ke-60.dunia?page=all.

Junaedhi, K. (2013). Ayat-ayat sastra. Jakarta: KKK

Kompas.com. (2016). Minat Baca Indonesia Ada di Urutan ke-60. Diakses dari https://edukasi.kompas.com/read/2016/08/29/07175131/minat.baca.indonesi a.ada.di.urutan.ke-60.dunia?page $=$ all

Wellek, R \& Warren, A. (1995). Teori kesusastraan. Jakarta: Gramedia

Wulandari, I. (2015). Jampang English Viollage, Beternak Sembari Berbahasa Inggris. Diakses pada 30 September 2019 dari https://khazanah.republika.co.id/berita/nm02rh/jampang-english-villagebeternak-sembari-berbahasa-inggris. 